\title{
Overexpression of RNF I 26 Promotes the Development of Colorectal Cancer via Enhancing p53 Ubiquitination and Degradation [Corrigendum]
}

Wang S, Wang T, Wang L, Zhong L, Li K. Onco Targets Ther. 2020;13:10917-10929.

The authors have advised due to an error at the time of figure assembly, Figure 6A on page 10926 is incorrect. The correct Figure 6 is shown below.
The authors apologize for this error and advise it does not affect the results of the paper. 

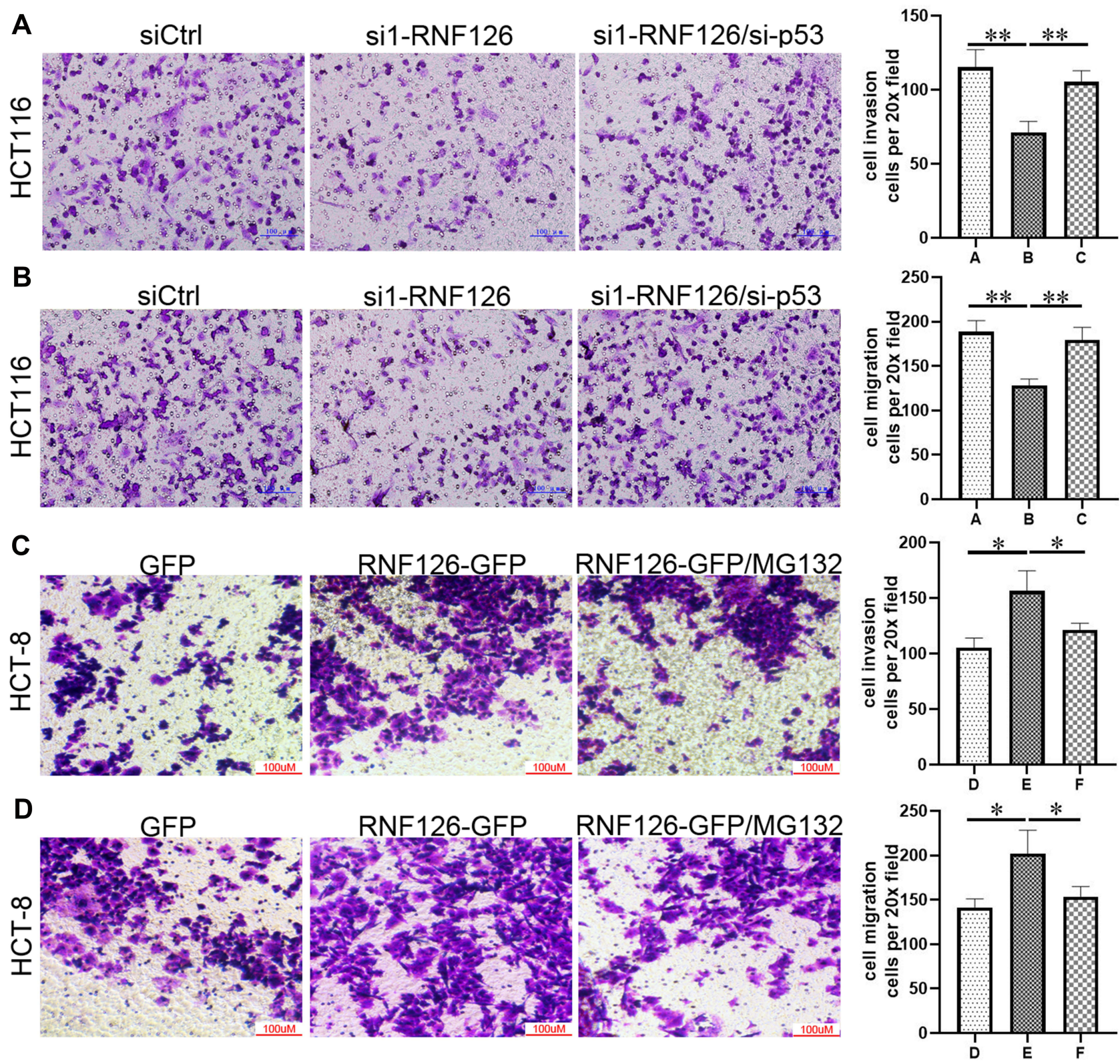

Figure 6 RNFI 26 promoted cell mobility in vitro in p53 dependent-ubiquitination. Cell invasion (A) and migration (B) in siCtrl, si I-RNFI 26 and si I-RNFI 26 plus si-p53 groups in HCTI I 6 cells. Cell invasion (C) and migration (D) in GFP, RNFI26-GFP, and RNFI26-GFP+MGI 32 groups of HCT-8 cells. (A) siCtrl group; (B) si I-RNFI 26 group; (C) si I-RNFI 26 group plus si-p53 group; (D) GFP group; (E) RNFI26-GFP group; (F) RNFI26-GFP group plus MGI 32 group. Bars indicate \pm SE. $* P<0.05$; $* * P<0.01$ compared with the control.

\section{Publish your work in this journal}

OncoTargets and Therapy is an international, peer-reviewed, open access journal focusing on the pathological basis of all cancers, potential targets for therapy and treatment protocols employed to improve the management of cancer patients. The journal also focuses on the impact of management programs and new therapeutic agents and protocols on patient perspectives such as quality of life, adherence and satisfaction. The manuscript management system is completely online and includes a very quick and fair peer-review system, which is all easy to use. Visit http://www.dovepress.com/ testimonials.php to read real quotes from published authors. 